\title{
Effects of glucagon infusions on protein and amino acid composition of milk from dairy cows ${ }^{1}$
}

\author{
G. Bobe ${ }^{2}$ A. R. Hippen, P. She, G. L. Lindberg, J. W. Young, and D. C. Beitz ${ }^{3}$ \\ Nutritional Physiology Group, Department of Animal Science, lowa State University, Ames 50011
}

\begin{abstract}
Changing the composition of milk proteins and AA affects the nutritional and physical properties of dairy products. Intravenous infusions of glucagon decreases milk protein production and concentration by promoting the use of gluconeogenic blood AA for hepatic glucose synthesis. Little is known about how the diversion of AA to gluconeogenesis affects the composition of milk proteins and AA. The objective was to quantify changes in composition of milk protein and AA in response to i.v. glucagon infusions. Three separate experiments were used: 1) 8 Holstein cows were fed ad libitum and infused with glucagon at $10 \mathrm{mg} / \mathrm{d}$ for $14 \mathrm{~d}, 2) 7$ Holstein cows were feed restricted and infused with glucagon at $10 \mathrm{mg} / \mathrm{d}$ for $14 \mathrm{~d}$, and 3) 4 Brown Swiss cows were infused with glucagon at 5 and $10 \mathrm{mg} / \mathrm{d}$ for $2 \mathrm{~d}$ each. Milk and milk component yields and milk protein and amino acid composition of samples, collected with blood samples at the first and last day of the glucagon infusion period, were compared with those collected 1 $\mathrm{d}$ before and after the glucagon infusion period. Glucagon infusions decreased milk protein production and concentration in each experiment by at least $0.2 \pm$ $0.05 \mathrm{~kg} / \mathrm{d}$ and $4 \pm 0.4 \mathrm{~g} / \mathrm{L}$, respectively. The decrease was accompanied by changes in milk protein composition, the most consistent being an increase in $\kappa$-casein $(1.68 \pm 0.27 \%)$. Overall, glucagon infusions resulted in

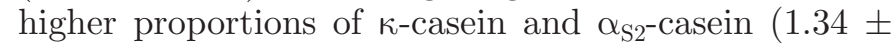
$0.51 \%)$ and smaller proportions of $\alpha_{S 1}$-casein $(-3.83 \pm$ $1.75 \%)$ and $\alpha$-lactalbumin $(-0.91 \pm 0.32 \%)$. Glucagon had little impact on milk AA composition except an increase in glycine $(0.26 \pm 0.11 \%)$. The results suggest that milk protein synthesis is regulated by many factors including AA and glucose availability.
\end{abstract}

\footnotetext{
Received June 12, 2008.

Accepted August 26, 2008.

${ }^{1}$ Publication of the Iowa Agriculture and Home Economics Experiment Station, Ames, Project Number 3801.

${ }^{2}$ G. Bobe (bobeg@mail.nih.gov) is currently a fellow in the Cancer Prevention Fellowship Program, Office of Preventive Oncology, National Cancer Institute, National Institutes of Health, Bethesda,

${ }^{3}$ Corresponding author: dcbeitz@iastate.edu
} MD 20892.
Key words: dairy cow, glucagon, milk protein composition, milk amino acid composition

\section{INTRODUCTION}

Milk protein composition has gained interest from manufacturers and consumers because it affects the nutritional and physical properties and yield of dairy products (Amenu and Deeth, 2007). Therefore, altering milk protein composition by selective breeding or nutrition could be useful to the dairy industry. Genetics, in particular milk protein polymorphisms, play a major role in regulating milk protein composition (Bobe et al., 1999; Graml and Pirchner, 2003) and, thus, could change milk protein composition.

The role of nutrition on milk protein composition is less conclusive. Several studies examined how increasing the supply of selected AA alters milk protein composition. The results were inconsistent (Pacheco-Rios et al., 1999; Hadrová et al., 2007). Injections of atropine decreased concentrations of plasma AA and insulin and, consequently, decreased milk protein synthesis. Synthesis of $\alpha-\mathrm{LA}$ and $\beta$-LG seems affected more than is synthesis of CN proteins; however, this effect was not evaluated statistically (Auldist et al., 2003). Insulin infusions plus glucose to minimize blood glucose changes increase milk yield and milk protein synthesis. Milk protein composition under these conditions was altered toward smaller proportions of $\beta-\mathrm{CN}$ and greater proportions of $\alpha$-LA and $\beta$-LG (Mackle et al., 1999).

Infusions of glucagon, a gluconeogenic hormone and antagonist of insulin, decreased milk protein production and concentration in dairy cows (Hippen et al., 1999a,b; She et al., 1999). A potential mechanism by which glucagon decreased milk protein production and concentration is that glucagon promoted liver gluconeogenesis from blood AA, thereby limiting the availability of gluconeogenic AA for milk protein synthesis (Bobe et al., 2003). The differential effect of glucagon on plasma concentrations of individual AA might be reflected in milk AA composition, favoring synthesis of milk proteins that are lower in the most limited AA. Therefore, glucagon infusions could be a useful tool to examine the regulation of milk protein synthesis. 
The objective of this study, which used a subset of cows and samples from previous studies (Hippen et al., 1999a,b; She et al., 1999), was to examine whether glucagon infusions alter composition of proteins and AA profiles of milk from dairy cows and whether glucagon infusions can help to elucidate mechanisms by which milk protein synthesis is regulated.

\section{MATERIALS AND METHODS}

\section{Experimental Design}

All 3 experiments were conducted at the Iowa State University Dairy Teaching Farm between October 1994 and April 1996. Cows were managed and treated in accordance with guidelines established by the Iowa State University Committee on Animal Care.

Experiment 1. Multiparous Holstein cows $(\mathrm{n}=8)$ were used that had a postpartum ratio of liver triacylglycerol to glycogen $<1.5$ at d 6 postpartum. Cows were fed during the dry period according to NRC recommendations (NRC, 1988). After parturition, cows had ad libitum access to a diet formulated to meet NRC recommendations (NRC, 1988) for lactating cows. Fresh feed was offered daily at 0800,1600 , and 2400 $\mathrm{h}$. Orts were removed before the $0800 \mathrm{~h}$ feeding. Cows were milked daily at 0800,1600 , and $2400 \mathrm{~h}$.

Starting at d 21 postpartum, each cow was confined to a tie stall and glucagon was infused i.v. for $14 \mathrm{~d}$. Lyophilized glucagon (donated by Eli Lilly \& Co., Indianapolis, IN) was dissolved in $0.15 \mathrm{M} \mathrm{NaCl}$ (preadjusted to $\mathrm{pH} 10.25$ ) at $20.83 \mathrm{mg} / \mathrm{L}$ to provide $10 \mathrm{mg} / \mathrm{d}$ of glucagon when infused at $20 \mathrm{~mL} / \mathrm{h}$ via a volumetric pump (Infu-Check model 1500; IVAC Corp., San Diego, CA). At d 35 postpartum, infusions were ended by decreasing the infusion rate by $2 \mathrm{~mL} / \mathrm{h}$ over a $10-\mathrm{h}$ period. The experimental design was described by She et al. (1999).

Experiment 2. Multiparous Holstein cows $(\mathrm{n}=7)$ were used that had a postpartum ratio of liver triacylglycerol to glycogen $>2.5$ at d 6 postpartum. In addition to their regular dry period diets, fed to meet NRC recommendations (NRC, 1988), cows were offered 5 to $6 \mathrm{~kg}$ of cracked corn daily during the final $30 \mathrm{~d}$ of the dry period. For the first $14 \mathrm{~d}$ postpartum, cows had ad libitum access to a diet formulated to meet NRC recommendations (NRC, 1988). The feeding and milking schedule was the same as for experiment 1. Starting at d 14 postpartum, each cow was confined to a tie stall and cows were feed restricted for $28 \mathrm{~d}$ to limit their energy intake to $\leq 80 \%$ of NRC recommendations (NRC, 1988). The diet was supplemented with up to 1.4 L/d of 1, 3-butanediol to induce ketosis (Mills et al., 1986). Starting at d 21 postpartum, glucagon solution was prepared and infused i.v. for $14 \mathrm{~d}$ as described for experiment 1 . The experimental design was described by Hippen et al. (1999b).

Experiment 3. Four early lactation Brown Swiss cows ( $35 \pm 4$ DIM, 2 primiparous and 2 multiparous) were used in a crossover design. Cows had been fed during the dry period according to NRC recommendations (NRC, 1988). After parturition, cows had ad libitum access to a diet formulated to meet NRC recommendations (NRC, 1988). Fresh feed was offered daily at 0800, 1600 , and $2400 \mathrm{~h}$. Uneaten feed was removed before the $0800 \mathrm{~h}$ feeding. Cows were milked daily at 1200 and $2400 \mathrm{~h}$.

Glucagon was infused i.v. for $4 \mathrm{~d}$ during which cows were confined to a tie stall. Dissolved glucagon, prepared as described for experiment 1, provided 5 or 10 $\mathrm{mg} / \mathrm{d}$ of glucagon when infused at 10 or $20 \mathrm{~mL} / \mathrm{h}$. Each cow received the dosage of glucagon assigned for the first $48 \mathrm{~h}$ and was then switched for another $48 \mathrm{~h}$ to the other dosage. The experimental design was described by Hippen et al. (1999a).

\section{Sample Collection and Chemical Analyses}

Milk yield and feed intake were recorded, and milk samples were collected $1 \mathrm{~d}$ before and after each glucagon infusion period and on the first and last day of the glucagon infusion. In experiments 1 and 2, collections were on d 20,22, 34, and 36 postpartum. In experiment 3 , collections were on $\mathrm{d}-1,1,4$, and 5 relative to initiation of glucagon infusion. Milk samples were preserved with $\mathrm{K}_{2} \mathrm{Cr}_{2} \mathrm{O}_{7}(1 \mathrm{mg} / 1 \mathrm{~mL}$ of milk; Sigma Aldrich, St. Louis, MO) and sent refrigerated to Swiss Valley Farms (Davenport, IA) to be analyzed for total fat, protein, and lactose by mid-infrared spectrophotometry (MilkO-Scan 203, Foss Food Technology Corp., Eden Prairie, $\mathrm{MN})$. For further statistical analysis, the average fat, protein, and lactose concentration for each day was computed. Protein concentration was based on total nitrogen concentration and did not exclude NPN.

A second aliquot was composited (on a proportional basis to milk produced at each milking) into a daily sample for each cow and used to determine relative amounts (wt \%) of milk proteins by using reversephase HPLC (Bobe et al., 1998). Briefly, a solution containing 0.1 $M$ BisTris buffer ( $\mathrm{pH}$ 6.8), $6 M$ guanidine hydrochloride, $5.37 \mathrm{~m} M$ sodium citrate, and 19.5 $\mathrm{m} M$ dithiothreitol ( $\mathrm{pH} 7$ ) was added directly to frozen aliquots in a 1:1 ratio (vol:vol) at room temperature. After thawing, each sample was shaken for $10 \mathrm{~s}$, incubated for $1 \mathrm{~h}$ at room temperature, and centrifuged for 5 min at $16,000 \times g$ in a microcentrifuge. The fat layer was removed with a spatula. The remaining solubilized sample was diluted 1:3 (vol:vol) with a solution contain- 
ing 4.5 $M$ guanidine hydrochloride and solvent $\mathrm{A}$, which consisted of acetonitrile, water, and trifluoroacetic acid in a ratio 100:900:1 (vol:vol:vol; pH 2). Milk proteins were separated from a $20-\mu \mathrm{L}$ sample on a silica-based C-18 RP-HPLC column $(250 \mathrm{~mm}$ length $\times 4.6 \mathrm{~mm}$ i.d., Microsorb MV C-18, particle size: $5 \mu \mathrm{m}$, pore size: $30 \mathrm{~nm}$ ) that was preceded by a filter (pore size: 0.5 $\mu \mathrm{m}$; both from Rainin Instruments, Woburn, MA). A solvent gradient program was run at a flow rate of 1.2 $\mathrm{mL} / \mathrm{min}$ from $73 \%$ of solvent A and $27 \%$ of solvent B, containing acetonitrile, water, and trifluoroacetic acid in a ratio 900:100:1 (vol:vol:vol; $\mathrm{pH} 2$ ), to $49.8 \%$ of solvent A and $50.2 \%$ of solvent B. Milk proteins were detected at $220 \mathrm{~nm}$ and quantified by comparing peak areas with peak areas of samples with known amounts of milk proteins.

A third aliquot was composited (on a proportional basis to milk produced at each milking) into a daily sample for each cow and used to determine relative amounts (mol \%) of milk AA in the Protein Facility of Iowa State University (Ames, IA) using a Perkin Elmer Applied Biosystems Model 420A phenylthiocarbamyl (PTC) derivatizer with an on-line Perkin Elmer Applied Biosystems Model 130A PTC AA analyzer (Applied Biosystems, Foster City, CA). Samples were hydrolyzed at $150^{\circ} \mathrm{C}$ with $6 \mathrm{M} \mathrm{HCl}$ for 65 min under vacuum (vapor-phase hydrolysis). Limitations of acid hydrolysis are that Trp, Cys/cystine, amino sugars, and phosphorylated AA cannot be quantified because they were 50 to $100 \%$ degraded or modified and that Asn and Gln are quantitatively hydrolyzed to Asp and Glu, respectively. In addition, the concentrations of Ser, Thr, Tyr, Met, Ala, Ile, and Val were underestimated because Ser, Thr, and Tyr are 5 to $20 \%$ degraded, Met is partly altered, and the bonds of some aliphatic AA such as Ala-Ala, Ile-Ile, Val-Val, Val-Ile, Ile-Val, and Ala-Val were particularly resistant to acid hydrolysis. Pre-column PTC derivatization was used before detection and quantification of the PTC-derivatized AA at $254 \mathrm{~nm}$ on a reverse-phase HAISIL PTC column $(2.1 \times$ 220 mm, $5 \mu \mathrm{m}, 100 \AA$; The Nest Group, Southborough, MA). The procedure is described in greater detail at http://www.protein.iastate.edu/aaa.html.

Blood was collected from a second jugular vein catheter into a $10-\mathrm{mL}$ vacutainer tube (Becton Dickinson and Co., Rutherford, NJ) containing $\mathrm{Na}_{2}$-EDTA and stored on ice until plasma was prepared within $2 \mathrm{~h}$. For glucagon determination, aprotinin (BoehringerMannheim, Indianapolis, IN) was added at $500 \mathrm{kIU}$ to 1 $\mathrm{mL}$ of plasma. Sampling times were $1 \mathrm{~d}$ before the start of infusion (experiments 1 and 2) or directly before the start of infusion (experiment 3), $24 \mathrm{~h}$ after the start of infusion, $24 \mathrm{~h}$ before the end of infusion, and $1 \mathrm{~d}$ after the end of infusion. Plasma was stored at $-20^{\circ} \mathrm{C}$ until analysis of glucagon, insulin, and IGF-I by RIA (Vicini et al., 1991; Hippen et al., 1999b) and of glucose and urea $\mathrm{N}$ with a microcentrifugal autoanalyzer (Monarch Plus, Instrumentation Laboratories, Lexington, MA). The detection limits for plasma glucagon, insulin, and IGF-I were $13 \mathrm{pg} / \mathrm{mL}, 100 \mathrm{pg} / \mathrm{mL}$, and $1 \mathrm{ng} / \mathrm{mL}$, respectively. The inter- and intraassay CV for glucagon and insulin were below 5 and 10\%, respectively. According to Vicini et al. (1991), the IGF-I intra- and interassay CV were 11.0 and $9.0 \%$, respectively. Of all the data values, the only values outside the linear ranges were for IGF-I. In experiment 1, 1 cow had IGF-I values at 1 time point below the detection limit. In experiment 2,1 cow had IGF-I values at 1 time point and another cow at 2 time points below the detection limit. The IGF-I values below the detection limit $(<1 \mathrm{ng} / \mathrm{mL})$ were set equal to 0.01 .

\section{Statistical Analyses}

Data were analyzed as a repeated measures study by using a multivariate regression model with multiple correlated variance components in PROC MIXED of SAS Version 9.1.3 (SAS Institute, 2004). There is no random effect in the model, although the MIXED statement suggested otherwise. Using the UN option in the REPEATED statement, a completely unrestricted variance-covariance structure was used to account for repeated measures taken on individual cows across time. The fixed effects in the model were experiment $(\mathrm{n}=3)$, time (day before start of infusion, first day of infusion, last day of infusion, day after end of infusion), and the interaction of experiment $\times$ time. To obtain the correct degrees of freedom, the KENWARDROGER option was invoked. The KENWARDROGER option consists of the Satterthwaite adjustment for degrees of freedom with a Kenward-Roger adjustment on SE, which can be used for repeated measures studies.

The effects of glucagon infusions on milk and blood variables were evaluated using a $t$-test in the ESTIMATE statement and comparing the estimated values during the infusion period (first and last day of infusion) with those before and after the infusion period (day before and after the infusion). Potential interactions between experiments and glucagon infusions were evaluated using a $t$-test in the CONTRAST statement and comparing a) the effects of infusions in Holsteins (experiments 1 and 2) with those in Brown Swiss cows (experiment 3) and b) the effects in Holsteins fed ad libitum (experiment 1) with those feed restricted (experiment 2). The 2 glucagon dosages used in experiment 3 were treated as 1 after no differential effects of dosages were verified. Significance was declared at $P$ $\leq 0.05$, and trends toward significance were declared 
at $P \leq 0.10$. Means and SEM presented in tables are least-squares means and the largest SEM of the 4 time points.

\section{RESULTS AND DISCUSSION}

Glucagon infusions decreased milk protein production and concentration without major effects on milk yield or on other milk components (Table 1). The effect of $10 \mathrm{mg} / \mathrm{d}$ of glucagon infusion on milk protein was large with an average decrease of $20 \%(229 \pm 29 \mathrm{~g} / \mathrm{d} ; P<$ $0.0001)$ and $17 \%(5.20 \pm 0.28 \mathrm{~g} / \mathrm{L} ; P<0.0001)$ for yield and concentration, respectively. Similarly, Trevisi et al. (1997) reported an approximate 15\% decrease in milk protein concentration in 2 lactating cows infused with 3.5 to $7 \mathrm{mg} / \mathrm{d}$ of glucagon. In comparison, the decrease in milk protein concentration in response to decreasing AA supply was $12 \%$ in mid-lactation Holstein cows (Weekes et al., 2006). Insulin infusions, in combination with a euglycemic clamp, had minimal effects on milk protein concentration. When $\mathrm{CN}$ or branched-chain AA were infused additionally, milk protein concentration increased by $10 \%$ and milk yield increased by 10 to $15 \%$ (Griinari et al., 1997; Mackle et al., 1999).

The effect of glucagon on milk protein production and concentration was reproducible and consistent. In all 3 experiments milk protein production and concentration were decreased by at least 17 and $14 \%$, respectively (Table 1). The smallest decrease was detected in Holsteins fed ad libitum (experiment 1), and the largest decrease was in Holsteins feed restricted, thereby limiting their AA supply (experiment 2). Dosage of glucagon, type of administration (continuous infusion versus multiple injections), and energy status of cows might affect the milk protein response to glucagon (Hippen et al., 1999a,b; Bobe et al., 2003). In comparison, the response of milk protein yield and concentration to AA infusions has been inconsistent (Cant et al., 2003; Doepel et al., 2004). The differences in experimental design among the atropine (Luimes et al., 2002; Auldist et al., 2003) and the insulin plus AA studies (Griinari et al., 1997; Mackle et al., 1999) were too large to evaluate the reproducibility of the effects of atropine and insulin, respectively.

The effects of glucagon on milk proteins were rapid, as exemplified by the changes in milk protein composition within the first $24 \mathrm{~h}$ of glucagon infusion (Table 2). In addition, the effects of glucagon on milk proteins were short-term and stopped within $24 \mathrm{~h}$ after the end of the infusion period (Table 2). Similar results for glucagon responses have been reported by Trevisi et al. (1997). The milk protein response to atropine is also rapid; the authors, however, did not report how long the effects persisted after atropine infusions or injections
(Luimes et al., 2002; Auldist et al., 2003). In summary, the large, consistent, rapid, and short-term response of milk protein concentration to glucagon infusions would make glucagon infusions an attractive model to study the in vivo regulation of milk protein synthesis.

The most likely mechanism by which glucagon decreases milk protein concentration is that glucagon decreases AA availability and increases glucose availability to the mammary gland by increasing hepatic extraction of gluconeogenic AA for conversion to glucose, thereby decreasing arterial concentrations of gluconeogenic AA and increasing concentrations of glucose (Flakoll et al., 1994). This potential explanation is supported by our observations that $5 \mathrm{mg}$ of glucagon injections 8 $\mathrm{h}$ apart decrease $\alpha$-amino $\mathrm{N}$ concentrations in plasma from early lactation dairy cows by approximately $25 \%$ (Bobe et al., 2003) and, further, that glucagon infusions increase plasma glucose concentrations (Table 1). The increased glucose concentrations could explain why the lactose concentration in milk is increased (Cant et al., 2002); however, we did not observe this effect consistently (Table 1). Glucagon is unlikely to act directly on the mammary gland because glucagon does not bind to or affect synthesis rates in extracted mammary tissue (Robson et al., 1984). In addition, the effect of glucagon on milk proteins is unlikely mediated by lactogenic hormones such as insulin, because the decrease in milk protein synthesis was not associated with changes in insulin concentrations (Table 1; She et al., 1999).

Glucagon infusions altered milk protein composition toward more $\kappa-\mathrm{CN}$ and $\alpha_{\mathrm{S} 2}-\mathrm{CN}$ and less $\alpha_{\mathrm{S}^{2}}-\mathrm{CN}$ and $\alpha$-LA (Table 2). The most consistent effect was an increase in the proportion of $\kappa-\mathrm{CN}$, in particular of the glycosylated forms of $\kappa$-CN (Table 2), which elute before unglycosylated $\kappa$-CN. Glucagon infusions did not alter total synthesis of glycosylated $\kappa-\mathrm{CN}(1.19 \pm 1.51$ $\mathrm{g} / \mathrm{d} ; P=0.45)$, but increased concentrations of glycosylated $\kappa-\mathrm{CN}$ in milk $(0.081 \pm 0.035 \mathrm{~g} / \mathrm{L} ; P=0.03)$. We attribute the lack of change in synthesis of glycosylated $\kappa-\mathrm{CN}$ to increased plasma glucose concentrations following glucagon infusions (Table 1), thereby providing sufficient precursors for glycosylation to the mammary gland (Table 1). Our results suggest that $\kappa-\mathrm{CN}$ glycosylation is at least partly regulated independent of milk protein synthesis.

Glucagon infusions decreased preferentially the overall synthesis of the more abundant $\mathrm{CN}$ proteins $\alpha_{\mathrm{S} 1}{ }^{-} \mathrm{CN}$ $(-126 \pm 21 \mathrm{~g} / \mathrm{d} ; P<0.0001)$ and $\beta-\mathrm{CN}(-48 \pm 13$ $\mathrm{g} / \mathrm{d} ; P=0.003)$ compared with the less abundant $\mathrm{CN}$ proteins $\kappa-C N(-12 \pm 4 \mathrm{~g} / \mathrm{d} ; P=0.01)$ and $\alpha_{\mathrm{S}^{2}} \mathrm{CN}$ $(-3 \pm 6 \mathrm{~g} / \mathrm{d} ; P=0.65)$. One potential explanation is that glucagon affects the translational efficiency of CN mRNA transcripts, in particular those of $\alpha_{\mathrm{S} 1}-\mathrm{CN}$ and $\beta-\mathrm{CN}$, via limiting AA availability. Moshel et al. 


\begin{tabular}{|c|c|c|c|c|c|c|c|c|c|c|c|c|}
\hline \multirow[b]{3}{*}{ Variable } & \multicolumn{6}{|c|}{ Holsteins fed ad libitum (experiment 1) } & \multicolumn{6}{|c|}{ Holsteins fed restricted (experiment 2) } \\
\hline & \multirow[b]{2}{*}{$\begin{array}{c}\text { Before } \\
(\mathrm{n}=8)\end{array}$} & \multicolumn{2}{|c|}{ During infusion } & \multirow[b]{2}{*}{$(\mathrm{n}=8)$} & \multirow[b]{2}{*}{ SEM } & \multirow[b]{2}{*}{$P$-value } & \multirow[b]{2}{*}{$\begin{array}{c}\text { Before } \\
(\mathrm{n}=7)\end{array}$} & \multicolumn{2}{|c|}{ During infusion } & \multirow[b]{2}{*}{$(\mathrm{n}=7)$} & \multirow[b]{2}{*}{ SEM } & \multirow[b]{2}{*}{$P$-value } \\
\hline & & $\begin{array}{c}\text { Start } \\
(\mathrm{n}=8)\end{array}$ & $\begin{array}{c}\text { End } \\
(\mathrm{n}=8)\end{array}$ & & & & & $\begin{array}{c}\text { Start } \\
(\mathrm{n}=7)\end{array}$ & $\begin{array}{c}\text { End } \\
(\mathrm{n}=7)\end{array}$ & & & \\
\hline \multicolumn{13}{|l|}{ Amount } \\
\hline DMI (kg/d) & 32.65 & 36.44 & 37.33 & 42.55 & 3.12 & NS & 21.59 & 21.13 & 19.03 & 19.44 & 3.34 & NS \\
\hline Milk (kg/d) & 47.73 & 44.76 & 45.76 & 45.32 & 3.64 & NS & 32.49 & 30.68 & 21.87 & 23.07 & 3.89 & NS \\
\hline Protein $(\mathrm{kg} / \mathrm{d})$ & 1.313 & 1.050 & 1.160 & 1.345 & 0.105 & $* * *$ & 0.963 & 0.722 & 0.526 & 0.700 & 0.113 & $* * *$ \\
\hline Fat $(\mathrm{kg} / \mathrm{d})$ & 1.691 & 1.640 & 1.681 & 1.599 & 0.214 & NS & 1.630 & 1.523 & 1.165 & 1.186 & 0.294 & NS \\
\hline Lactose $(\mathrm{kg} / \mathrm{d})$ & 2.322 & 2.209 & 2.270 & 2.264 & 0.196 & NS & 1.559 & 1.476 & 1.059 & 1.127 & 0.210 & NS \\
\hline \multicolumn{13}{|l|}{ Concentration } \\
\hline \multicolumn{13}{|l|}{ Milk } \\
\hline Protein $(\mathrm{g} / \mathrm{L})$ & 27.69 & 23.62 & 25.50 & 29.73 & 0.97 & $* * *$ & 29.60 & 23.41 & 24.53 & 30.54 & 1.03 & $* * *$ \\
\hline Fat $(\mathrm{g} / \mathrm{L})$ & 35.45 & 36.24 & 36.12 & 35.36 & 3.05 & NS & 50.32 & 49.68 & 53.87 & 51.79 & 3.26 & NS \\
\hline Lactose $(\mathrm{g} / \mathrm{L})$ & 48.66 & 49.35 & 49.47 & 49.79 & 0.81 & NS & 47.96 & 48.08 & 47.95 & 48.25 & 0.86 & NS \\
\hline \multicolumn{13}{|l|}{ Plasma } \\
\hline Glucagon $(\mathrm{pg} / \mathrm{mL})$ & 262 & 898 & 655 & 488 & 153 & $* * *$ & 78 & 685 & 557 & 184 & 164 & $* * *$ \\
\hline Insulin $(\mathrm{pg} / \mathrm{mL})$ & 434 & 707 & 437 & 670 & 167 & NS & 255 & 316 & 456 & 288 & 178 & NS \\
\hline IGF-I (ng/mL) & 60.31 & 65.23 & 77.67 & 60.35 & 13.60 & $*$ & 23.72 & 25.94 & 28.35 & 30.65 & 13.60 & NS \\
\hline Glucose (mg/dL) & 51.88 & 59.76 & 62.44 & 54.89 & 4.11 & $* *$ & 38.46 & 49.67 & 52.90 & 42.06 & 4.39 & $* *$ \\
\hline \multirow[t]{3}{*}{ Urea N (mg/dL) } & 19.41 & 19.40 & 18.14 & 18.98 & 1.42 & NS & 13.43 & 14.09 & 11.89 & 12.07 & 1.52 & NS \\
\hline & \multicolumn{6}{|c|}{ Brown Swiss fed ad libitum (experiment 3) } & \multicolumn{6}{|c|}{ Overall } \\
\hline & $(\mathrm{n}=4)$ & $(\mathrm{n}=4)$ & $(\mathrm{n}=4)$ & $(\mathrm{n}=4)$ & SEM & $P$-value & $(\mathrm{n}=19)^{2}$ & $(\mathrm{n}=19)$ & $(\mathrm{n}=19)$ & $(\mathrm{n}=19)$ & SEM & $P$-value \\
\hline \multicolumn{13}{|l|}{ Amount } \\
\hline DMI (kg/d) & $\mathrm{ND}^{3}$ & ND & ND & ND & & & 27.12 & 28.78 & 28.18 & 31.00 & 2.29 & NS \\
\hline Milk (kg/d) & 31.79 & 27.55 & 35.19 & 37.36 & 5.15 & NS & 37.34 & 34.33 & 34.27 & 35.25 & 2.47 & $\dagger$ \\
\hline Protein (kg/d) & 0.996 & 0.736 & 0.903 & 1.155 & 0.149 & $* * *$ & 1.090 & 0.836 & 0.863 & 1.066 & 0.071 & $* * * 4$ \\
\hline Fat $(\mathrm{kg} / \mathrm{d})$ & 1.323 & 1.338 & 1.680 & 2.203 & 0.303 & $*$ & 1.548 & 1.500 & 1.509 & 1.663 & 0.145 & $\dagger$ \\
\hline Lactose $(\mathrm{kg} / \mathrm{d})$ & 1.607 & 1.488 & 1.890 & 1.866 & 0.278 & NS & 1.829 & 1.724 & 1.740 & 1.752 & 0.133 & NS \\
\hline \multicolumn{13}{|l|}{ Concentration } \\
\hline \multicolumn{13}{|l|}{ Milk } \\
\hline Protein $(\mathrm{g} / \mathrm{L})$ & 31.44 & 26.63 & 25.73 & 31.60 & 1.37 & $* * *$ & 29.58 & 24.55 & 25.25 & 30.62 & 0.66 & $* * *$ \\
\hline Fat $(\mathrm{g} / \mathrm{L})$ & 42.43 & 48.19 & 47.34 & 57.14 & 4.32 & NS & 42.70 & 44.70 & 45.78 & 48.10 & 2.07 & NS \\
\hline Lactose $(\mathrm{g} / \mathrm{L})$ & 50.41 & 54.09 & 53.65 & 49.46 & 1.14 & $* * *$ & 49.01 & 50.50 & 50.36 & 49.175 & 0.55 & $* * * 5$ \\
\hline Plasma & & & & & & & & & & & & \\
\hline Glucagon $(\mathrm{pg} / \mathrm{mL})$ & ND & ND & ND & ND & & & 170 & 792 & 606 & 335 & 112 & $* * *$ \\
\hline Insulin $(\mathrm{pg} / \mathrm{mL})$ & ND & ND & ND & ND & & & 345 & 511 & 446 & 479 & 122 & NS \\
\hline IGF-I (ng/mL) & ND & ND & ND & ND & & & 42.01 & 45.58 & 53.01 & 45.50 & 9.62 & $* * *$ \\
\hline Glucose (mg/dL) & 51.88 & 59.76 & 62.44 & 54.89 & 5.81 & $*$ & 50.46 & 58.93 & 60.45 & 47.00 & 2.79 & $\dagger$ \\
\hline Urea N (mg/dL) & 20.38 & 20.25 & 17.80 & 18.70 & 2.01 & NS & 17.74 & 17.91 & 15.94 & 16.58 & 0.97 & NS \\
\hline
\end{tabular}

${ }^{1}$ In experiments 1 and 2, glucagon was administered at $10 \mathrm{mg} / \mathrm{d}$ from d 21 to 35 postpartum. In experiment 3 , glucagon was administered at 5 and $10 \mathrm{mg} / \mathrm{d}$ for $2 \mathrm{~d}$ at each dosage.

${ }^{2}$ In experiment 3, DMI were not determined $1 \mathrm{~d}$ before glucagon infusion, and plasma glucagon, insulin, and IGF-I concentrations were not determined at any time point. Therefore, the number of samples for those variables for each time point is 15 rather than 19 .

${ }^{3} \mathrm{ND}=$ not determined.

${ }^{4}$ Interaction between restricted- and ad libitum-fed Holsteins $(P=0.005)$.

${ }^{5}$ Interaction between Holsteins and Brown Swiss cows $(P<0.0001)$.

NS $>0.10 ; \dagger P \leq 0.10 ; * P \leq 0.05 ;{ }^{* *} P \leq 0.01 ;{ }^{* * *} P \leq 0.001$. 
Table 2. Effect of i.v. infusions of glucagon on milk protein composition presented as least squares means

\begin{tabular}{|c|c|c|c|c|c|c|c|c|c|c|c|c|}
\hline \multirow[b]{3}{*}{$\begin{array}{l}\text { Proportion of total } \\
\text { protein }(\mathrm{wt} \%)\end{array}$} & \multicolumn{6}{|c|}{ Holsteins fed ad libitum (experiment 1) } & \multicolumn{6}{|c|}{ Holsteins fed restricted (experiment 2) } \\
\hline & \multirow[b]{2}{*}{$\begin{array}{c}\text { Before } \\
(\mathrm{n}=6)^{2}\end{array}$} & \multicolumn{2}{|c|}{ During infusion } & \multirow[b]{2}{*}{$\begin{array}{c}\text { After } \\
(\mathrm{n}=8)\end{array}$} & \multirow[b]{2}{*}{ SEM } & \multirow[b]{2}{*}{$P$-value } & \multirow[b]{2}{*}{$\begin{array}{l}\text { Before } \\
(\mathrm{n}=7)\end{array}$} & \multicolumn{2}{|c|}{ During infusion } & \multirow[b]{2}{*}{$\begin{array}{c}\text { After } \\
(\mathrm{n}=7)\end{array}$} & \multirow[b]{2}{*}{ SEM } & \multirow[b]{2}{*}{$P$-value } \\
\hline & & $\begin{array}{c}\text { Start } \\
(\mathrm{n}=6)\end{array}$ & $\begin{array}{l}\text { End } \\
(\mathrm{n}=8)\end{array}$ & & & & & $\begin{array}{c}\text { Start } \\
(\mathrm{n}=7)\end{array}$ & $\begin{array}{c}\text { End } \\
(\mathrm{n}=7)\end{array}$ & & & \\
\hline Casein & 85.00 & 84.22 & 80.70 & 82.17 & 2.12 & NS & 85.18 & 85.75 & 83.22 & 83.53 & 2.27 & NS \\
\hline Total к-Casein & 12.82 & 14.15 & 14.44 & 12.33 & 0.84 & $* * *$ & 12.30 & 14.89 & 14.24 & 13.17 & 0.76 & $* * *$ \\
\hline Glycos. ${ }^{3}{ }^{\kappa}$-Casein & 4.15 & 5.32 & 5.29 & 4.21 & 0.50 & $* * *$ & 4.68 & 6.73 & 7.06 & 6.42 & 0.47 & $* * *$ \\
\hline$\alpha_{\mathrm{S}^{2}}$-Casein & 8.02 & 9.55 & 11.42 & 8.12 & 1.32 & $* *$ & 7.37 & 9.51 & 7.72 & 7.03 & 1.41 & $\dagger$ \\
\hline$\alpha_{S_{1}-\text { Casein }}$ & 41.75 & 38.36 & 33.76 & 39.90 & 3.07 & $\dagger$ & 44.48 & 36.24 & 37.84 & 42.64 & 3.28 & $*$ \\
\hline$\beta$-Casein & 22.77 & 22.28 & 21.08 & 21.83 & 2.15 & NS & 21.02 & 25.11 & 23.42 & 20.68 & 2.29 & $\dagger$ \\
\hline Whey & 15.00 & 15.78 & 19.30 & 17.83 & 2.12 & NS & 14.82 & 14.25 & 16.78 & 16.47 & 2.27 & NS \\
\hline$\alpha-L A$ & 4.50 & 3.90 & 5.44 & 5.64 & 0.86 & NS & 3.91 & 2.78 & 2.85 & 4.07 & 0.87 & $*$ \\
\hline \multirow[t]{3}{*}{$\beta-\mathrm{LG}$} & 10.40 & 11.49 & 13.86 & 12.19 & 1.78 & NS & 10.91 & 11.47 & 13.93 & 12.40 & 1.90 & NS \\
\hline & \multicolumn{6}{|c|}{ Brown Swiss fed ad libitum (experiment 3) } & \multicolumn{6}{|c|}{ Overall } \\
\hline & $(\mathrm{n}=4)$ & $(\mathrm{n}=4)$ & $(\mathrm{n}=4)$ & $(\mathrm{n}=4)$ & SEM & $P$-value & $(\mathrm{n}=17)$ & $(\mathrm{n}=17)$ & $(\mathrm{n}=19)$ & $(\mathrm{n}=19)$ & SEM & $P$-value \\
\hline Casein & 83.40 & 86.37 & 84.06 & 84.89 & 3.00 & NS & 84.53 & 85.45 & 82.66 & 83.53 & 1.44 & NS \\
\hline Total к-Casein & 11.98 & 13.52 & 14.04 & 12.62 & 1.10 & $*$ & 12.37 & 14.19 & 14.24 & 12.71 & 0.53 & $* * *$ \\
\hline Glycos. k-Casein & 4.17 & 5.75 & 6.35 & 4.91 & 0.62 & $* * *$ & 4.33 & 5.93 & 6.23 & 5.18 & 0.31 & $* * *$ \\
\hline$\alpha_{S_{2}}$-Casein & 5.62 & 6.33 & 5.42 & 5.76 & 1.87 & NS & 7.01 & 8.46 & 8.19 & 6.97 & 0.90 & $*$ \\
\hline$\alpha_{S_{1}-\text { Casein }}$ & 39.26 & 39.68 & 37.37 & 38.19 & 4.34 & NS & 41.83 & 38.09 & 36.23 & 40.24 & 2.08 & $*$ \\
\hline$\beta$-Casein & 26.53 & 26.85 & 27.23 & 28.32 & 1.50 & NS & 23.44 & 24.75 & 23.91 & 23.61 & 1.46 & NS \\
\hline Whey & 16.60 & 13.63 & 15.94 & 15.11 & 3.00 & NS & 15.47 & 14.55 & 17.34 & 16.47 & 1.44 & NS \\
\hline$\alpha-L A$ & 5.88 & 4.10 & 3.94 & 4.44 & 1.15 & NS & 4.76 & 3.59 & 4.07 & 4.50 & 0.55 & $*$ \\
\hline$\beta-\mathrm{LG}$ & 10.72 & 9.53 & 12.00 & 10.68 & 2.51 & NS & 10.68 & 10.83 & 13.27 & 11.75 & 1.21 & NS \\
\hline
\end{tabular}

I In experiments 1 and 2 , glucagon was administered at $10 \mathrm{mg} / \mathrm{d}$ from d 21 to 35 postpartum. In experiment 3 , glucagon was administered at 5 and $10 \mathrm{mg} / \mathrm{d}$ for $2 \mathrm{~d}$ at each dos-

일. ${ }^{2}$ A second aliquot of milk was not collected from 2 cows at the beginning of the glucagon injection period for milk protein and AA composition.

₹ $\quad{ }^{3}$ Glycos. = glycosylated.

을. $\quad \mathrm{NS}>0.10 ; \dagger P \leq 0.10 ; * P \leq 0.05 ; * * P \leq 0.01 ; * * * P \leq 0.001$. 


\begin{tabular}{|c|c|c|c|c|c|c|c|c|c|c|c|c|}
\hline \multirow[b]{3}{*}{$\begin{array}{l}\text { Proportion of total } \\
\text { milk AA (mol\%) }\end{array}$} & \multicolumn{6}{|c|}{ Holsteins fed ad libitum (experiment 1) } & \multicolumn{6}{|c|}{ Holsteins fed restricted (experiment 2) } \\
\hline & \multirow[b]{2}{*}{$\begin{array}{l}\text { Before } \\
(\mathrm{n}=5)^{2}\end{array}$} & \multicolumn{2}{|c|}{ During infusion } & \multirow[b]{2}{*}{$\begin{array}{c}\text { After } \\
(\mathrm{n}=8)\end{array}$} & \multirow[b]{2}{*}{ SEM } & \multirow[b]{2}{*}{$P$-value } & \multirow[b]{2}{*}{$\begin{array}{l}\text { Before } \\
(\mathrm{n}=7)\end{array}$} & \multicolumn{2}{|c|}{ During infusion } & \multirow[b]{2}{*}{$\begin{array}{c}\text { After } \\
(\mathrm{n}=7)\end{array}$} & \multirow[b]{2}{*}{ SEM } & \multirow[b]{2}{*}{$P$-value } \\
\hline & & $\begin{array}{c}\text { Start } \\
(\mathrm{n}=6)^{2}\end{array}$ & $\begin{array}{c}\text { End } \\
(\mathrm{n}=8)\end{array}$ & & & & & $\begin{array}{c}\text { Start } \\
(\mathrm{n}=7)\end{array}$ & $\begin{array}{l}\text { End } \\
(\mathrm{n}=7)\end{array}$ & & & \\
\hline Aspartic acid $^{3}$ & 10.36 & 10.85 & 10.92 & 10.22 & 0.42 & $*$ & 10.69 & 9.97 & 10.44 & 10.57 & 0.42 & NS \\
\hline Glutamic acid ${ }^{4}$ & 17.91 & 18.41 & 18.56 & 18.48 & 1.08 & NS & 17.17 & 17.09 & 16.95 & 16.94 & 1.15 & NS \\
\hline Serine & 5.69 & 5.64 & 5.60 & 5.58 & 0.26 & NS & 5.87 & 6.22 & 5.90 & 5.65 & 0.28 & $*$ \\
\hline Glycine & 4.49 & 4.84 & 4.74 & 4.32 & 0.30 & $*$ & 4.94 & 4.90 & 5.16 & 4.75 & 0.32 & NS \\
\hline Histidine & 2.04 & 1.90 & 2.08 & 1.97 & 0.09 & NS & 1.90 & 1.91 & 1.83 & 1.89 & 0.09 & NS \\
\hline Arginine & 1.97 & 1.96 & 1.92 & 1.96 & 0.10 & NS & 1.98 & 2.13 & 2.11 & 2.04 & 0.09 & $\dagger$ \\
\hline Threonine & 5.02 & 4.89 & 5.01 & 4.88 & 0.25 & NS & 5.12 & 5.25 & 4.90 & 4.74 & 0.26 & NS \\
\hline Alanine & 6.46 & 6.62 & 6.68 & 6.45 & 0.37 & NS & 6.78 & 6.50 & 7.31 & 7.39 & 0.40 & NS \\
\hline Proline & 8.49 & 7.97 & 7.69 & 8.45 & 0.61 & NS & 8.38 & 9.02 & 8.67 & 8.73 & 0.57 & NS \\
\hline Tyrosine & 1.33 & 1.24 & 1.22 & 1.42 & 0.11 & NS & 1.15 & 1.23 & 1.27 & 1.26 & 0.11 & NS \\
\hline Valine & 6.74 & 6.64 & 6.58 & 6.69 & 0.15 & NS & 6.69 & 6.73 & 6.65 & 6.99 & 0.21 & NS \\
\hline Methionine & 0.75 & 0.78 & 0.72 & 0.85 & 0.15 & NS & 0.63 & 0.82 & 0.61 & 0.59 & 0.13 & NS \\
\hline Isoleucine & 4.22 & 4.06 & 4.10 & 4.24 & 0.24 & NS & 3.75 & 3.80 & 3.56 & 3.60 & 0.24 & NS \\
\hline Leucine & 12.48 & 12.26 & 12.48 & 12.60 & 0.42 & NS & 13.21 & 12.94 & 12.94 & 13.40 & 0.45 & $\dagger$ \\
\hline Phenylalanine & 3.09 & 2.87 & 2.87 & 3.12 & 0.16 & $\dagger$ & 2.90 & 3.10 & 2.91 & 2.94 & 0.17 & NS \\
\hline \multirow[t]{3}{*}{ Lysine } & 8.69 & 8.79 & 8.85 & 8.79 & 0.30 & NS & 8.85 & 8.40 & 8.80 & 8.86 & 0.32 & $\dagger$ \\
\hline & \multicolumn{6}{|c|}{ Brown Swiss fed ad libitum (experiment 3) } & \multicolumn{6}{|c|}{ Overall } \\
\hline & $(\mathrm{n}=3)^{2}$ & $(\mathrm{n}=4)$ & $(\mathrm{n}=4)$ & $(\mathrm{n}=4)$ & SEM & $P$-value & $(\mathrm{n}=16)$ & $(\mathrm{n}=17)$ & $(\mathrm{n}=19)$ & $(\mathrm{n}=19)$ & SEM & $P$-value \\
\hline Aspartic acid & 10.59 & 10.07 & 10.14 & 9.44 & 0.55 & NS & 10.55 & 10.30 & 10.50 & 10.08 & 0.27 & $\mathrm{NS}^{5}$ \\
\hline Glutamic acid & 16.57 & 15.91 & 15.21 & 16.17 & 1.53 & NS & 17.21 & 17.13 & 16.90 & 17.19 & 0.73 & NS \\
\hline Serine & 5.52 & 5.60 & 5.74 & 5.70 & 0.37 & NS & 5.69 & 5.82 & 5.75 & 5.64 & 0.18 & NS \\
\hline Glycine & 4.19 & 4.31 & 4.58 & 4.28 & 0.42 & NS & 4.54 & 4.68 & 4.83 & 4.45 & 0.20 & $*$ \\
\hline Histidine & 1.78 & 1.76 & 1.71 & 1.98 & 0.11 & $\dagger$ & 1.90 & 1.85 & 1.87 & 1.95 & 0.06 & $\dagger$ \\
\hline Arginine & 2.23 & 2.13 & 2.18 & 2.27 & 0.13 & NS & 2.06 & 2.07 & 2.07 & 2.09 & 0.06 & NS \\
\hline Threonine & 4.94 & 5.37 & 5.34 & 5.28 & 0.35 & $\dagger$ & 5.03 & 5.17 & 5.08 & 4.97 & 0.17 & $\dagger$ \\
\hline Alanine & 7.16 & 7.07 & 7.44 & 6.60 & 0.52 & NS & 6.80 & 6.73 & 7.14 & 6.81 & 0.25 & NS \\
\hline Proline & 7.67 & 7.45 & 7.22 & 8.80 & 0.75 & $\dagger$ & 8.18 & 8.15 & 7.86 & 8.66 & 0.45 & $\dagger$ \\
\hline Tyrosine & 1.51 & 1.32 & 1.46 & 1.64 & 0.15 & NS & 1.33 & 1.26 & 1.32 & 1.44 & 0.07 & NS \\
\hline Valine & 6.61 & 6.88 & 6.85 & 6.99 & 0.21 & NS & 6.68 & 6.75 & 6.69 & 6.77 & 0.10 & NS \\
\hline Methionine & 1.08 & 1.10 & 1.13 & 1.26 & 0.19 & NS & 0.82 & 0.90 & 0.82 & 0.90 & 0.09 & NS \\
\hline Isoleucine & 5.18 & 5.34 & 5.06 & 5.05 & 0.32 & NS & 4.39 & 4.40 & 4.24 & 4.29 & 0.15 & NS \\
\hline Leucine & 12.91 & 13.00 & 13.41 & 12.66 & 0.60 & NS & 12.87 & 12.73 & 12.94 & 12.88 & 0.29 & $\mathrm{NS}^{6}$ \\
\hline Phenylalanine & 3.09 & 3.15 & 3.18 & 3.41 & 0.23 & NS & 3.03 & 3.04 & 2.99 & 3.16 & 0.11 & NS \\
\hline Lysine & 9.42 & 9.56 & 9.37 & 8.49 & 0.42 & $*$ & 8.99 & 8.91 & 9.01 & 8.72 & 0.20 & $\mathrm{NS}^{6}$ \\
\hline
\end{tabular}

${ }^{1}$ In experiments 1 and 2, glucagon was administered at $10 \mathrm{mg} / \mathrm{d}$ from d 21 to 35 postpartum. In experiment 3 , glucagon was administered at 5 and $10 \mathrm{mg} / \mathrm{d}$ for $2 \mathrm{~d}$ at each dosage.

${ }^{2} \mathrm{~A}$ second aliquot of milk was not collected from 2 cows at the beginning of the glucagon injection period for milk protein and AA composition. Two samples were excluded from statistical analysis because the samples were run separately from the other samples of the same cow.

${ }^{3}$ Contains asparagine.

${ }^{4}$ Contains glutamine.

${ }^{5}$ Interaction between restricted- and ad libitum-fed Holsteins $(P=0.01)$

${ }^{6}$ Interaction between Holsteins and Brown Swiss cows $(P \leq 0.05)$.

NS $>0.10 ; \dagger P \leq 0.10 ; * P \leq 0.05 ; * * P \leq 0.01 ; * * * P \leq 0.001$ 
(2006) showed that availability of AA, specifically Leu, alters translational efficiency of milk proteins in bovine mammary epithelial cells. A differential effect on $\mathrm{CN}$ synthesis was reported for various types of interventions. Insulin infusions (in combination with a euglycemic clamp), and dietary supplementation of rumen-protected Lys, Met, and His increase CN concentrations with a stronger effect on synthesis of $\beta-\mathrm{CN}$ than on synthesis of $\kappa-\mathrm{CN}$ and $\alpha-\mathrm{CN}$ (combined $\alpha_{\mathrm{S} 1}-\mathrm{CN}$ and $\alpha_{\mathrm{S}_{2}} \mathrm{CN}$ ) in milk (Mackle et al., 1999; Hadrová et al., 2007). Feeding rumen-protected Met and Lys preferentially increased concentrations of $\beta-\mathrm{CN}$ and $\alpha-\mathrm{CN}$ but not of $\kappa-\mathrm{CN}$ (Donkin et al., 1989). Later studies, however, did not confirm those results (Colin-Schoellen et al., 1995; Pacheco-Rios et al., 1999). In contrast, atropine injections and infusions of branched-chain AA affect the synthesis of all $\mathrm{CN}$ proteins similarly (Auldist et al., 2003; Mackle et al., 1999).

Glucagon infusions decreased the synthesis of both $\alpha$-LA $(-17 \pm 4 \mathrm{~g} / \mathrm{d} ; P=0.002)$ and $\beta-\mathrm{LG}(-18 \pm 8$ $\mathrm{g} / \mathrm{d} ; P=0.05)$, resulting in a decrease in the relative proportion of $\alpha$-LA $(P=0.02)$, but not of $\beta$-LG $(P=$ 0.20 ) in milk protein (Table 2). Similarly, atropine injections, which decrease plasma AA and insulin concentrations, preferentially decrease concentrations of $\alpha-\mathrm{LA}$ in milk (Auldist et al., 2003); however, the effect has not been consistent for all studies (Roets and Peeters, 1981). In contrast, bST injections preferentially increase a-LA synthesis (Eppard et al., 1985) and insulin infusions (in combination with a euglycemic clamp) tend to preferentially increase synthesis of $\alpha-\mathrm{LA}$ and $\beta-\mathrm{LG}$ (Mackle et al., 1999). No effects on the synthesis of $\alpha-L A$ and $\beta-L G$ were reported for dietary supplementation of rumen-protected Met alone or in combination with Lys (Colin-Schoellen et al., 1995; Pacheco-Rios et al., 1999).

Glucagon infusions had little impact on milk AA composition. The only significant overall change was an increase in glycine (Table 3). Glucagon preferentially promotes hepatic extraction of gluconeogenic and nonessential AA from blood, whereas branched-chain AA (Leu, Ile, and Val) are not affected (Flakoll et al., 1994). We hypothesized that glucagon infusions would change milk AA composition toward a profile that reflects AA availability to the mammary gland. Although we did not measure blood AA composition, our results on milk AA composition do not support this hypothesis (Table 3). Similarly, other studies showed that various dietary interventions have little impact on milk AA composition (Hadrová et al., 2007), which suggests that synthesis of individual milk proteins is not regulated exclusively by AA availability. Future studies should examine the effects of AA supplementation during glucagon infusions on synthesis of individual milk proteins and AA. In addition, future studies are warranted to examine the effects of endogenous glucagon on synthesis of individual milk proteins and AA because this study used supraphysiological dosages of glucagon to cause large changes in the availability of glucose and AA to peripheral tissues such as the mammary gland.

In conclusion, our results demonstrate that glucagon infusions, under various conditions, result in a rapid and short-term decrease in protein yield and concentration with minimal effects on milk yield or on other milk components in early lactation cows. We hypothesize that glucagon infusions alter milk protein synthesis by promoting hepatic uptake and conversion of AA to glucose, which primarily decreases the availability of AA and increases the availability of glucose to the mammary gland. This makes administration of glucagon an attractive model to examine the role of increased glucose availability and decreased AA availability to the mammary gland on synthesis of milk proteins. Infusions of glucagon alter milk protein composition toward higher proportions of $\kappa-\mathrm{CN}$, specifically glycosylated $\kappa-\mathrm{CN}$, and $\alpha_{\mathrm{S}^{2}} \mathrm{CN}$ and smaller proportions of $\alpha_{\mathrm{S} 1^{-}} \mathrm{CN}$ and $\alpha$-LA. That effect suggests the synthesis of milk proteins is partly regulated at the posttranscriptional level. In contrast, milk AA composition was minimally altered by glucagon, suggesting that AA and glucose availability are only 2 of many elements that can alter milk protein synthesis.

\section{ACKNOWLEDGMENTS}

The authors thank Swiss Valley Farms (Davenport, IA) for analysis of milk samples and the Protein Facility at Iowa State University (Ames), in particular J. Nott and L. Tabatabai, for milk AA analysis. Appreciation for provision, care, and sampling of cows from the Iowa State University Dairy Farms is extended to D. Crawley, C. Achen, J. Kent, and J. Beck. Laboratory assistance was provided by S. Deng and C. Sharp. We thank Eli Lilly (Indianapolis, IN) for donation of glucagon and analysis of blood samples for urea $\mathrm{N}$ and glucose. We thank Monsanto (St. Louis, MO) for analysis of blood samples for IGF-I. The project was partly supported by National Research Initiative Competitive Grant No. 1993-37201-9343 from the USDA Cooperative State Research, Education, and Extension Research, and was part of regional research project NC-185. G. Bobe was supported in part by a scholarship from the National Milk Producers Federation (Arlington, VA).

\section{REFERENCES}

Amenu, B., and H. C. Deeth. 2007. The impact of milk composition on cheddar cheese manufacture. Aust. J. Dairy Technol. 62:171184. 
Auldist, M. J., C. M. Menzies, and C. G. Prosser. 2003. Effects of atropine on plasma amino acid profiles and on the synthesis of individual milk proteins in dairy cows fed with pasture. J. Dairy Res. 70:373-378.

Bobe, G., B. N. Ametaj, J. W. Young, and D. C. Beitz. 2003. Potential treatment of fatty liver with 14-day subcutaneous injections of glucagon. J. Dairy Sci. 86:3138-3147.

Bobe, G., D. C. Beitz, A. E. Freeman, and G. L. Lindberg. 1998. Separation and quantification of bovine milk proteins by reversedphase high-performance liquid chromatography. J. Agric. Food Chem. 46:458-463.

Bobe, G., D. C. Beitz, A. E. Freeman, and G. L. Lindberg. 1999. Effect of milk protein genotypes on milk protein composition and its genetic parameter estimates. J. Dairy Sci. 82:2797-2804.

Cant, J. P., R. Berthiaume, H. Lapierre, P. H. Luimes, B. W. McBride, and D. Pacheco. 2003. Responses of the bovine mammary glands to absorptive supply of single amino acids. Can. J. Anim. Sci. 83:341-355.

Cant, J. P., D. R. Trout, F. Qiao, and N. G. Purdie. 2002. Milk synthetic response of the bovine mammary gland to an increase in the local concentrations of arterial glucose. J. Dairy Sci. 85:494503.

Colin-Schoellen, O., F. Laurent, B. Vignon, J. C. Robert, and B Sloan. 1995. Interactions of ruminally protected methionine and lysine with protein source or energy level in the diets of cows. J. Dairy Sci. 78:2807-2818.

Doepel, L., D. Pacheco, J. J. Kennelly, M. D. Hanigan, I. F. López, and H. Lapierre. 2004. Milk protein synthesis as a function of amino acid supply. J. Dairy Sci. 87:1279-1297.

Donkin, S. S., G. A. Varga, T. F. Sweeney, and L. D. Muller. 1989 Rumen-protected methionine and lysine: Effects on animal performance, milk protein yield, and physiological measures. J. Dairy Sci. 72:1484-1491.

Eppard, P. J., D. E. Bauman, J. Bitman, D. L. Wood, R. M. Akers, and W. A. House. 1985. Effect of dose of bovine growth hormone on milk composition: $\alpha$-Lactalbumin, fatty acids, and mineral elements. J. Dairy Sci. 68:3047-3054.

Flakoll, P. J., M. J. Borel, L. S. Wenzel, P. E. Williams, D. B. Lacy, and N. N. Abumrad. 1994. The role of glucagon in the control of protein and amino acid metabolism in vivo. Metabolism 43:1509 1516.

Graml, R., and F. Pirchner. 2003. Effects of milk protein loci on content of their proteins. Arch. Tierz. Dummerstorf 46:331-340.

Griinari, J. M., M. A. McGuire, D. A. Dwyer, D. E. Bauman, D. M. Barbano, and W. A. House. 1997. The role of insulin in the regulation of milk protein synthesis in dairy cows. J. Dairy Sci. 80:2361-2371.

Hadrová, S., L. Køížová, M. Bjelka, J. Tøináctý, and M. Draèková. 2007. The effect of administration of soya-protein with Lys, Met, and His in two forms on casein yield and composition and AA profile in milk. J. Anim. Feed Sci. 16:3-17.
Hippen, A. R., P. She, J. W. Young, D. C. Beitz, G. L. Lindberg, L. F. Richardson, and R. W. Tucker. 1999a. Metabolic responses of dairy cattle to various dosages of glucagon. J. Dairy Sci. 82:11281138.

Hippen, A. R., P. She, J. W. Young, D. C. Beitz, G. L. Lindberg, L. F. Richardson, and R. W. Tucker. 1999b. Alleviation of fatty liver in dairy cows with 14-day intravenous infusions of glucagon. J. Dairy Sci. 82:1139-1152.

Luimes, P. H., J. P. Cant, X. Zaho, and D. Petitclerc. 2002. Delineating potential control mechanisms of mammary protein synthesis using atropine. J. Dairy Sci. 85:1445-1453.

Mackle, T. R., D. A. Dwyer, K. L. Ingvartsen, P. Y. Chouinard, J. M. Lynch, D. M. Barbano, and D. E. Bauman. 1999. Effects of insulin and amino acids on milk protein concentration and yield from dairy cows. J. Dairy Sci. 82:1512-1524.

Mills, S. E., D. C. Beitz, and J. W. Young. 1986. Characterization of metabolic changes during a protocol for inducing lactation ketosis in dairy cows. J. Dairy Sci. 69:362-370.

Moshel, Y., R. E. Rhoads, and I. Barash. 2006. Role of amino acids in translational mechanisms governing milk protein synthesis in murine and ruminant mammary epithelial cells. J. Cell. Biochem. 98:685-700.

NRC. 1988. Nutrient Requirements of Dairy Cattle. 6th rev. ed. Natl. Acad. Press, Washington, DC.

Pacheco-Rios, D., W. C. McNabb, J. P. Hill, T. N. Barry, and D. D. S. Mackenzie. 1999. The effects of methionine supplementation upon milk composition and production of forage-fed dairy cows. Can. J. Anim. Sci. 79:235-241.

Robson, N. A., R. A. Clegg, and V. A. Zammit. 1984. Regulation of peripheral lipogenesis of glucagon. Biochem. J. 217:743-749.

Roets, E., and G. Peeters. 1981. Effect of atropine on plasma amino acid levels and milk secretion of cows. J. Dairy Res. 48:23-34.

SAS Institute. 2004. SAS ${ }^{\circledast}$ User's Guide: Statistics, Version 9.1. SAS Inst. Inc., Cary, NC.

She, P., A. R. Hippen, J. W. Young, G. L. Lindberg, D. C. Beitz, L. F. Richardson, and R. W. Tucker. 1999. Metabolic responses of lactating dairy cows to 14-day intravenous infusions of glucagon. J. Dairy Sci. 82:1118-1127.

Trevisi, E., G. Folli, and G. Bertoni. 1997. Effect of long term infusion of insulin and glucagon on milk yield and composition of dairy cows. Pages 415-421 in Animal Production: Advances in Technology, Accuracy, and Management. Proc. XXXII Int. Symp. Soc. Italiana per il Progresso della Zootecnica, Milan, Italy. Elsevier, Paris, France.

Vicini, J. L., F. C. Buonomo, J. J. Veenhuizen, M. A. Miller, D. R. Clemmons, and R. J. Collier. 1991. Nutrient balance and stage of lactation affect responses of insulin, insulin-like growth factors I and II, and insulin-like growth factor-binding protein 2 to somatotropin administration in dairy cows. J. Nutr. 121:1656-1664.

Weekes, T. L., P. H. Luimes, and J. P. Cant. 2006. Responses to amino acid imbalances and deficiencies in lactating dairy cows. J. Dairy Sci. 89:2177-2187. 